\title{
Stability Analysis in Pigeonpea (Cajanus cajan (L.) Millspaugh) Genotypes for Yield and its Component Traits
}

\author{
Deepak Pal, S. K. Verma, Amit Kumar Gaur ${ }^{*}$, Charupriya Chauhan, \\ Anandi Karn, Harikant Yadav and Harshdeep \\ Department of Genetics and Plant Breeding, G.B. Pant University of Agriculture and \\ Technology, Pantnagar, Uttarakhand-263145, India \\ *Corresponding author
}

Keywords

Pigeonpea, Stability, Genotype $\times$ Environment, Eberhart and Russell

\section{Article Info}

Accepted: 04 August 2020 Available Online: 10 September 2020

\begin{abstract}
A B S T R A C T
The present study was conducted with seventeen advanced lines of pigeonpea along with three checks (Pusa 992, Paras and UPAS 120). The experiment at each location was laid out in a Randomized Block Design (RBD) with three replications. The result of pooled ANOVA revealed that $G \times E$ interaction was significant for most of the characters except number of primary branches/plant, number of secondary branches/plant, number of seeds/pod, main shoot length and seed yield per plot. The presence of significant $\mathrm{G} \times \mathrm{E}$ is must as further analysis is possible only if there is a reliable genotype $\mathrm{x}$ environment interaction and hence, for number of primary branches/plant, number of secondary branches/plant, number of seeds/pod, main shoot length and seed yield/plot no further analysis was carried out. The traits in which $\mathrm{G}$ x E interaction was found significant were analysed by using Eberhart and Russell's model and it was found that for days to 50\% flowering, the check Paras was found as most stable across all environments however for days to maturity, plant height and 100-seed weight none of the genotype was found to be stable across all environments. The most stable genotypes exhibiting higher stability for number of pod/plant across all environments was PA 538 followed by PA 540.
\end{abstract}

\section{Introduction}

Among all the pulses cultivated in India, pigeonpea [Cajanus cajan (L.) Mill sp] holds most important status as it is a multipurpose legume and highly suitable for cultivation in rainfed areas under low input conditions or even under the condition of drought. It has tremendous potential to solve the challenge of global food production under the threat of climate change, soil degradation and increasing production costs (Saxena et al., 2016).Nearly all parts of pigeonpea are used for one or other purposes like grains and green pods as human food, leaves as animal fodder, woody stem as fuel and for making huts (Verma et al., 2018). Pigeonpea can also play an important role in crop diversification by rotating the rice-wheat cropping system to pigeonpea-wheat cropping system.In India during 2017-18 cropping season, it was grown on 4.43 million hectare area with production 
of 4.25 million tons, with a productivity level of about $960 \mathrm{~kg} / \mathrm{ha}$ (Anonymous, 2018). Pigeonpea is grown almost all over the country, however, the major states in terms of area and production are Maharashtra, Karnataka, Tamil Nadu, Madhya Pradesh, Rajasthan, Gujarat, Bihar and Uttar Pradesh which together account for $86 \%$ of national area and $83.8 \%$ of national production.

Plant phenotype is a function of genotype, environment and genotype $\mathrm{x}$ environment interaction. Genotype $\mathrm{x}$ environment interaction always affects the genotypic performance of varieties in broad range of environments (Gauch and Zobel, 1996).Genotype $x$ environment interaction is said to occur when different cultivars or genotypes respond differently to diverse environmental conditions. A significant genotype $\mathrm{x}$ environment interaction can seriously impair efforts in selecting superior genotypes for crop introductions and cultivar development programs (Yan and Racjan, 2002).The Genotype $x$ environment interaction undermines the repeatability of experimental results and hence reduces efficiency of selection (Kearsey and Pooni, 1996). Therefore, understanding the structure and nature of genotype $x$ environment interaction is of utmost usefulness to the plant breeders as it helps to determine whether to develop cultivars with wider adaptability or to develop cultivars for a specific targeted area.

The earliest attempt to analyse the stability of individual lines was made by Plaisted and Peterson (1959) but the method used was complex and not very effective in case of evaluation of large number of lines (Pabale and Pandya, 2010). After that several workers (Yates and Cochran, 1938; Mather and Jones, 1958 and Finlay and Wilkinson, 1963) proposed different statistical models for stability analysis but the model proposed by Eberhart and Russell (1966) was preferred method of stability analysis because of its simplicity and reliability. In Eberhart and Russell (1966) model, the stable genotypes were identified based on high mean yield, regression coefficient (bi) around unity and mean square deviations from regression $\left(\mathrm{s}^{2} \mathrm{di}\right)$ non significant from zero. The knowledge of $\mathrm{G} \times \mathrm{E}$ interaction and yield stability are important parameters for breeding new cultivars with improved adaptation to environmental constraints prevailing in the targeted environments (Meena et al., 2017 and Rao and Prabhakaran, 2000). Therefore, the present investigation was undertaken with the objective to study $G \times E$ interaction for yield and yield contributing characters and to identify stable advance lines of pigeonpea.

\section{Materials and Methods}

The experimental material used in present investigation consisted of seventeen early maturing advanced breeding lines of pigeonpea along with three checks viz. Pusa 992, Paras and UPAS120. The experiment was conducted at three different locations, two at the Norman E. Borlaug Crop Research Centre, Pantnagar (Pigeonpea Breeding Block) and Pigeonpea Entomology Block of G. B. Pant University of Agriculture and Technology, Pantnagar and the third at Agricultural Research Station, Majhera (Almora), G. B. Pant University of Agriculture and Technology, Pantnagar. Each genotype was grown in a 6 row plot of $4 \mathrm{~m}$ length with three replications. A row to row distance of $60 \mathrm{~cm}$ and plant to plant distance of $15 \mathrm{~cm}$ was maintained. All the recommended agronomic practices and plant protection measures were adopted to raise the uniform and normal healthy crop. At each location, observations were recorded on five randomly selected competitive plants from each genotype from each replication on 10 different morphological characters viz., days to $50 \%$ flowering, days to maturity, plant 
height $(\mathrm{cm})$, number of primary branches/plant, number of secondary branches/plant, number of pods/plant, number of seeds/pod, main shoot length $(\mathrm{cm}), 100$ seed weight $(\mathrm{g})$ and seed yield/plot $(\mathrm{g})$. The stability parameters were calculated as per the procedure given by Eberhart and Russell (1966) and three stability parameters mean (m), regression coefficient (bi) and the deviation from linearity $\left(\mathrm{S}^{2} \mathrm{di}\right)$ were estimated.

\section{Results and Discussion}

\section{Pooled Analysis of variance}

The results of pooled analysis of variance for ten characters over three different environments revealed that mean squares due to genotypes were significant for all the characters except number of primary branches/plant, number of seed/pod and main shoot length indicating the presence of enough genetic variability among the genotypes for these characters (Table 1). It is also evident from the table 1 that mean sum of square due to environment were significant for all the characters except days to maturity and number of primary branches/plant indicating that these traits were greatly influenced by environments. Similar findings for different characters were also reported earlier by Sawargaonkar et al., (2011), Pawar et al., (2013), Patel and Tikka (2014), Singh et al., (2015) Meena et al., (2017) and Gaur et al., (2020). Mean squares for $\mathrm{G} \times \mathrm{E}$ interaction was found to be significant for days to $50 \%$ flowering, days to maturity, plant height, number of pods/plant and 100 seed weight. However, for other traits such as number of primary branches/plant, number of secondary branches/plant, number of seeds/pod, main shoot length and seed yield/plot non- significant $\mathrm{G} \times \mathrm{E}$ is obtained indicating that these traits remained unaffected across environments. The presence of significant $\mathrm{G} \times \mathrm{E}$ is must as further analysis is possible only if there is a reliable genotype $\mathrm{x}$ environment interaction and hence, for number of primary branches/plant, number of secondary branches/plant, number of seeds/pod, main shoot length and seed yield/plot no further analysis was carried out. These findings are in agreement with the earlier findings of Verma and Bajpai (2002), Muthiah et al., (2005) and Gaur et al., (2020). The partitioning of mean squares (environment + genotypes $\times$ environments) showed that environment (linear) differed significantly and were quite diverse with respect to their effects on the performance of genotypes for all the traits except days to maturity and number of primary branches/plant. Further, higher value of mean squares due to environment (linear) as compared to genotype $\mathrm{x}$ environment (linear) displayed that linear response of environments accounted for the most of total variation for most of the traits under study. Similar findings in this regard were also obtained by Kumara et al., (2015). The significance of mean squares due to genotypes $\mathrm{x}$ environment (linear) component against pooled deviation were observed for days to $50 \%$ flowering, plant height, number of secondary branches/plant, number of pods/plant, main shoot length and seed yield/plot indicated that genotypes were diverse for their regression response to change with environment. Similar results for these characters were also observed by Meena et al., (2017). The significant mean squares due to pooled deviation were observed for all traits except plant height, number of pods/plant, number of seed/pod, main shoot length and seed yield/plot indicated that the deviation from linear regression also contributed substantially toward the differences in stability of genotypes. These findings are in agreement with the earlier findings of Sawargaonkar et al., (2011) and Kumara et al., (2015). 
Table.1 Pooled analysis of variance for different character in pigeonpea genotypes over three environment

\begin{tabular}{|c|c|c|c|c|c|c|c|c|c|c|c|}
\hline \multirow[t]{2}{*}{ Source of variation } & \multirow[t]{2}{*}{ d.f. } & \multicolumn{10}{|c|}{ Mean sum of square } \\
\hline & & $\begin{array}{c}\text { Days to } 50 \% \\
\text { flowering }\end{array}$ & $\begin{array}{c}\text { Days to } \\
\text { maturity }\end{array}$ & $\begin{array}{l}\text { Plant height } \\
\text { (cm) }\end{array}$ & $\begin{array}{l}\text { No. of primary } \\
\text { branches/plant }\end{array}$ & $\begin{array}{c}\text { No. of secondary } \\
\text { branches/plant }\end{array}$ & $\begin{array}{l}\text { Number of } \\
\text { pods/plant }\end{array}$ & $\begin{array}{l}\text { Number of } \\
\text { seed/pod }\end{array}$ & $\begin{array}{l}\text { Main shoot } \\
\text { length }(\mathrm{cm})\end{array}$ & $\begin{array}{l}100 \text { seed } \\
\text { weight }(\mathrm{g})\end{array}$ & Seed yield/plot \\
\hline Genotype & 19 & $26.05 * * *$ & $58.56^{* * *}$ & $469.07 *$ & 5.25 & $37.52 *$ & $2582.07 * *$ & 0.15 & 103.75 & $1.46^{* * *}$ & $129057.53 * * *$ \\
\hline Environment & 2 & $101.78 * * *$ & 36.85 & $43829.89 * * *$ & 7.62 & $135.21 * *$ & $59416.31 * * *$ & $0.80 * *$ & $6732.05^{* * *}$ & $0.69 * *$ & $6920868.50 * * *$ \\
\hline $\mathbf{G} \times \mathbf{E}$ & 38 & $9.24 * * *$ & $22.55 * * *$ & $262.56 * * *$ & 3.97 & 19.00 & $1189.36^{*}$ & 0.12 & 99.90 & $0.13 * * *$ & 46077.33 \\
\hline $\mathbf{E}+(\mathbf{G} \times \mathbf{E})$ & 40 & 13.87 & 23.26 & 2440.93 & 4.15 & 24.81 & 4100.70 & 0.15 & 431.51 & 0.16 & 389816.89 \\
\hline E(Linear) & 1 & $203.57 * * *$ & 73.70 & $87659.78 * * *$ & 15.24 & $270.43 * * *$ & $118832.62 * * *$ & $1.60 * * *$ & $13464.10 * * *$ & $1.39 * *$ & $13841737.0 * * *$ \\
\hline $\mathbf{G} \times \mathbf{E}$ (Linear) & 19 & $15.03 * * *$ & 15.11 & $466.87 * * *$ & 1.24 & $28.78 * * *$ & $2289.56 * * *$ & 0.12 & $162.59 * * *$ & 0.10 & $84833.98 * * *$ \\
\hline Pooled deviation & 20 & $3.29 * * *$ & $28.48 * * *$ & 55.33 & $6.31 * * *$ & $8.76^{*}$ & 84.70 & 0.11 & 35.35 & $0.15^{* * *}$ & 6954.65 \\
\hline Pooled error & 114 & 1.113 & 1.79 & 229.56 & 3.34 & 15.13 & 83613.63 & 0.24 & 118.52 & 1.79 & 104999.32 \\
\hline
\end{tabular}

Table.2 Stability parameters for different traits in pigeonpea genotypes

\begin{tabular}{|c|c|c|c|c|c|c|c|c|c|c|c|c|c|c|c|c|}
\hline \multirow{2}{*}{$\begin{array}{c}\text { S. } \\
\text { No. }\end{array}$} & \multirow[t]{2}{*}{ Genotypes } & \multicolumn{3}{|c|}{ Days to $50 \%$ flowering } & \multicolumn{3}{|c|}{ Days to maturity } & \multicolumn{3}{|c|}{ Plant height (cm) } & \multicolumn{3}{|c|}{ Number of pod per plant } & \multicolumn{3}{|c|}{ 100-Seed weight } \\
\hline & & Mean & $\mathbf{b}_{\mathbf{i}}$ & $\mathbf{S}^{2} \mathbf{d}_{\mathrm{i}}$ & Mean & $\mathbf{b}_{\mathbf{i}}$ & $S^{2} d_{i}$ & Mean & $\mathbf{b}_{\mathbf{i}}$ & $\mathbf{S}^{2} \mathbf{d}_{\mathrm{i}}$ & Mean & $\mathbf{b}_{\mathbf{i}}$ & $S^{2} d_{i}$ & Mean & $\mathbf{b}_{\mathbf{i}}$ & $\mathbf{S}^{2} \mathbf{d}_{\mathrm{i}}$ \\
\hline 1 & PA 535 & 78.44 & 2.42 & 4.32 & 138.77 & 2.32 & $15.08 * *$ & 196.55 & 1.12 & $6.13 *$ & 163.55 & 1.39 & -171.01 & 7.23 & 0.31 & 0.04 \\
\hline 2 & PA 536 & 81.00 & 2.58 & $6.79 *$ & 142.33 & 1.97 & -0.08 & 196.00 & 1.25 & -75.54 & 188.00 & 1.62 & -174.42 & 7.47 & 2.36 & 0.32 \\
\hline 3 & PA 537 & 77.22 & 2.73 & $9.77 * *$ & 132.44 & 2.35 & $19.00 * *$ & 194.66 & 1.27 & -70.56 & 150.66 & 1.30 & -232.72 & 7.25 & 0.31 & -0.00 \\
\hline 4 & PA 538 & 83.55 & 0.50 & 0.26 & 143.44 & 1.54 & 1.81 & 234.88 & 1.52 & -15.84 & 228.00 & 0.94 & -244.06 & 8.45 & 2.35 & 0.16 \\
\hline 5 & PA 539 & 82.77 & 0.11 & 1.56 & 141.22 & -0.14 & -0.59 & 212.66 & 1.33 & -75.17 & 137.11 & 0.38 & -199.25 & 6.59 & 0.50 & 0.04 \\
\hline 6 & PA 540 & 82.66 & -0.13 & $7.65^{*}$ & 143.55 & 1.03 & 2.19 & 198.66 & 1.07 & $134.66^{* *}$ & 200.55 & 1.02 & -232.25 & 7.56 & 1.24 & 0.24 \\
\hline 7 & PA 541 & 79.22 & 2.4 & 1.07 & 141.66 & 4.04 & $89.47 * *$ & 210.55 & 1.33 & -74.49 & 201.33 & 1.68 & -228.21 & 7.18 & 2.54 & 0.20 \\
\hline 8 & PA 542 & 77.66 & 1.53 & 0.21 & 131.00 & 0.81 & -0.15 & 220.55 & 1.39 & -36.96 & 184.55 & 1.76 & $31.61 * *$ & 6.65 & 0.64 & 0.08 \\
\hline 9 & PA 543 & 79.55 & 0.25 & 3.50 & 132.33 & -1.77 & $57.96 * *$ & 211.44 & 1.13 & $70.96^{* *}$ & 181.00 & 0.10 & -79.18 & 7.48 & 0.43 & -0.01 \\
\hline 10 & PA 544 & 79.22 & -0.99 & 1.24 & 140.00 & -1.68 & $38.45 * *$ & 204.11 & 0.56 & -1.59 & 189.00 & 0.09 & -155.75 & 7.79 & 1.42 & 0.07 \\
\hline 11 & PA 545 & 81.66 & 2.58 & $6.79^{*}$ & 138.88 & 3.56 & $18.56^{* *}$ & 225.44 & 1.31 & -75.55 & 194.77 & 2.11 & -220.83 & 7.51 & -0.22 & -0.01 \\
\hline 12 & PA 546 & 78.33 & 2.11 & 3.48 & 136.55 & 2.46 & $14.82 * *$ & 202.88 & 0.73 & $183.79 * *$ & 190.66 & 0.92 & -222.79 & 6.32 & 0.67 & -0.01 \\
\hline 13 & PA 547 & 79.88 & -0.46 & 0.59 & 135.00 & -4.08 & $182.11^{* *}$ & 209.22 & 0.46 & -70.67 & 159.00 & -0.36 & -63.12 & 7.53 & -0.70 & 0.12 \\
\hline 14 & PA 548 & 79.33 & 1.36 & 1.37 & 137.00 & 1.44 & $5.68 *$ & 212.77 & 1.10 & $29.99 * *$ & 119.00 & 0.67 & -240.66 & 7.54 & -1.14 & 0.28 \\
\hline 15 & PA 549 & 82.11 & 0.89 & -0.36 & 141.66 & -0.57 & $4.41 *$ & 209.22 & 0.77 & -75.70 & 199.22 & 0.75 & -224.64 & 8.40 & 0.80 & 0.18 \\
\hline 16 & PA 550 & 85.00 & -0.49 & $5.10^{*}$ & 144.66 & -0.58 & $33.01 * *$ & 221.88 & 0.83 & -64.37 & 226.77 & 0.76 & $282.65^{* *}$ & 7.71 & 4.48 & 1.05 \\
\hline 17 & PA 551 & 82.33 & -0.64 & $4.94 *$ & 140.77 & -0.10 & $13.66^{* *}$ & 195.00 & 0.65 & -76.52 & 204.22 & 1.39 & -217.57 & 6.43 & 0.98 & 0.02 \\
\hline 18 & PUSA 992 & 78.33 & 0.80 & -0.01 & 138.22 & 2.75 & $24.86^{* *}$ & 192.22 & 0.58 & -75.40 & 140.33 & 1.04 & -221.92 & 8.83 & 0.83 & 0.01 \\
\hline 19 & PARAS & 72.00 & 0.94 & 0.02 & 130.44 & 2.29 & $11.59 * *$ & 184.66 & 0.59 & -76.50 & 153.00 & 1.35 & -149.53 & 6.37 & 0.82 & 0.00 \\
\hline 20 & UPAS 120 & 83.55 & 1.42 & 0.02 & 142.88 & 2.33 & $25.88 * *$ & 207.00 & 0.93 & $15.65^{* *}$ & 189.66 & 1.02 & -231.97 & 7.98 & 1.33 & -0.01 \\
\hline & General mean & 80.19 & 1.00 & & 138.64 & 1.00 & & 207.04 & 1.00 & & 180.02 & 1.00 & & 7.42 & 1.00 & \\
\hline
\end{tabular}


Phenotypic stability analysis based on Eberhart and Russell (1966) model

The study of $\mathrm{G} \times \mathrm{E}$ interactions is essential for identification of phenotypically stable genotypes and it includes the three parameters i.e. mean performance $(\mathrm{X})$, regression coefficient (bi) and deviation from regression ( $\left.\mathrm{S}^{2} \mathrm{di}\right)$. A genotype is said to be stable, if it had high mean performance above average of all genotypes, regression coefficient does not differ from unity and minimum deviation from regression. Genotypes with bi lesser than unity (bi $<_{1}$ ), do not respond favourably to improved environmental conditions and hence could be regarded as specifically adapted to poor environments when their mean performance is more than average. On the other hand, a genotype is said to be specially adapted to a favourable environment, when its regression is more than unity (bi $>1$ ), higher mean performance and have minimum deviation from regression. Such genotypes tend to respond favourably to better environment but perform poor in unfavourable environments.

The stability parameters viz., mean, linear regression coefficient (bi) and deviation from regression $\left(\mathrm{S}^{2} \mathrm{di}\right)$ for each character have been presented in (Table 2). Earliness is one of the most desirable traits in the pigeonpea breeding programmes. Farmers requires early maturing genotypes of pigeonpea which can be harvested before the sowing of the preceding wheat crop keeping this point in view investigation was done to identify early maturing and stable genotypes that can be grown under different zones of Uttarakhand. For days to $50 \%$ flowering, check Paras $\left(\overline{\mathrm{X}}_{=}\right.$ 72.00, bi $=0.94$ and $S^{2} \mathrm{di}=0.02$ ) exhibited low

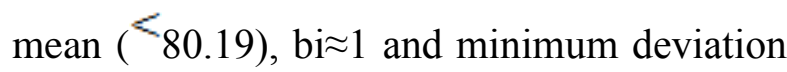
from regression and hence considered stable across all environments. The genotypes viz., PA $535\left({ }^{\bar{X}}=78.44\right.$, bi $=2.42$ and $\left.S^{2} d i=4.32\right)$,
PA $542\left(\bar{X}=77.66\right.$, bi $=1.53$ and $\left.S^{2} d i=0.21\right)$ and PA $546\left(\bar{X}=78.33\right.$, bi $=2.11$ and $\mathrm{S}^{2} \mathrm{di}$ $=3.48$ ) recorded low mean for flowering $(<80.19)$ along with (bi $>1)$, and minimum deviation from regression and hence suitable for favourable environment while the check Pusa 992( $X=78.33$, bi $=0.80$ and $\left.S^{2} \mathrm{di}=-0.01\right)$ had low mean for flowering $(<80.19)$ along with (bi < 1), and minimum deviation from regression and hence suitable for poor environment. Similar results were also reported by Sawargaonkar et al., (2011) and Meena et al., (2017). Similarly for days to maturity none of the genotype was found to be stable across environments as well as under favourable environment. However for days to maturity, PA $542(\bar{X}=131.00$, bi $=0.81$ and $S^{2} \mathrm{di}=-0.15$ ) was found suitable for suitable for poor environment because of low mean $(<138.64)$ along with (bi $<1)$, and minimum deviation from regression.

Plant height is another important trait in pigeonpea breeding programmes as the plant height has positive correlation with yield(Gaur et al., 2018).For plant height the most desirable and stable genotypes for rich environment were PA $538\left(\overline{\mathrm{x}}_{=} 234.88\right.$, bi $=1.52$ and $\left.\mathrm{S}^{2} \mathrm{di}=-15.84\right)$, PA $539\left(\overline{\mathrm{X}}_{=}=212.66\right.$, bi $=1.33$ and $\left.\mathrm{S}^{2} \mathrm{di}=-75.17\right)$, PA $541\left(\overline{\mathrm{x}}_{=}\right.$ 210.55, bi $=1.33$ and $\left.\mathrm{S}^{2} \mathrm{di}=-74.49\right)$ and $\mathrm{PA}$ $542\left({ }^{\bar{X}}=220.55\right.$, bi $=1.39$ and $\left.S^{2} \mathrm{di}=-36.96\right)$ due to high mean $(>207.04)$, bi $>1$ and minimum deviation from regression while for poor environment PA $547 \quad\left({ }^{\bar{X}}=209.22\right.$, bi $=0.46$ and $\left.S^{2} \mathrm{di}=-70.67\right)$, PA $549\left({ }^{\bar{X}}=209.22\right.$, bi $=0.77$ and $\left.\mathrm{S}^{2} \mathrm{di}=-75.70\right), \quad \mathrm{PA} 550$ $\left(\bar{X}=221.88\right.$, bi $=0.83$ and $\left.S^{2} \mathrm{di}=-64.37\right)$ were found suitable due to high mean ( $>207.04)$, bi $<_{1}$ and minimum deviation from regression. None of the genotype as well as check was found stable under all environments. Stability of genotypes for plant height was also 
observed by Sawargaonkar et al., (2011) and Meena et al., (2017).

The most desirable and suitable genotypes exhibiting higher stability for number of pod $/$ plant were PA $538(\mathrm{X}=228.00$, bi $=0.94$ and $S^{2}$ di $\left.=-244.06\right)$, PA $540 \quad\left({ }^{\bar{X}}=200.55\right.$, bi $=1.02$ and $\left.\mathrm{S}^{2} \mathrm{di}=-232.25\right)$, PA $546\left({ }^{\overline{\mathrm{X}}}=190.66\right.$, bi $=0.92$ and $\left.\mathrm{S}^{2} \mathrm{di}=-222.79\right)$ and UPAS $120\left({ }^{\bar{X}}=189.66\right.$, bi $=1.02$ and $S^{2}$ di $\left.=-231.97\right)$ due to high mean $(>180.02)$, bi $\approx 1$ and minimum deviation from regression. The most desirable and stable genotypes for number of pods/plant under rich environment were PA $536\left({ }^{\bar{X}}=188.00\right.$, bi $=1.62$ and $S^{2} \mathrm{di}=$ 174.42), PA $541\left({ }^{\bar{X}}=201.33\right.$, bi $=1.68$ and $S^{2} \mathrm{di}$ $=-228.21)$ and PA $545\left({ }^{\bar{X}}=194.77\right.$, bi $=2.11$ and $\mathrm{S}^{2} \mathrm{di}=-220.83$ ) due to high mean $(>180.02), \mathrm{bi}>1$ and minimum deviation from regression while for poor environment PA $544\left({ }^{\bar{X}}=189.00\right.$, bi $=0.09$ and $\left.S^{2} \mathrm{di}=-155.75\right)$ and PA $549\left({ }^{\bar{X}}=199.22\right.$, bi $=0.75$ and $S^{2}$ di $=$ 224.64) were found suitable due to high mean (>180.02), bi <1 and minimum deviation from regression. Stability of genotypes for number of pods/plant was also observed by Sawargaonkar et al., (2011), Patel and Tikka (2014)and Meena et al., (2017).For 100 seed weight genotypes PA $538\left({ }^{\bar{X}}=8.45\right.$, bi $=2.35$ and $\left.\mathrm{S}^{2} \mathrm{di}=0.16\right)$, PA $540\left({ }^{\bar{X}}=7.56\right.$, bi $=1.24$ and $\left.\mathrm{S}^{2} \mathrm{di}=0.24\right)$, PA $544\left({ }^{\overline{\mathrm{X}}}=7.79\right.$, bi $=1.42$ and $\left.\mathrm{S}^{2} \mathrm{di}=0.07\right)$, PA $548\left(\mathrm{X}^{\mathrm{X}}=7.54\right.$, bi $=-1.14$ and $\left.\mathrm{S}^{2} \mathrm{di}=0.28\right)$, PA $550(\overline{\mathrm{X}}=7.71$, bi $=4.48$ and $\left.\mathrm{S}^{2} \mathrm{di}=1.05\right)$ and UPAS $120(\mathrm{X}=7.98$, bi $=1.33$ and $S^{2}$ di $\left.=-0.01\right)$ were suitable for rich environment because of high mean $(>7.42)$, bi $>1$ and minimum $\mathrm{S}^{2}$ di nearly zero. The genotypes PA $545\left({ }^{\bar{X}}=7.51\right.$, bi $=-0.22$ and $S^{2}$ di $=-0.01)$, PA $547\left(\bar{X}_{=7.53}\right.$, bi $=-0.70$ and $S^{2} \mathrm{di}$ $=0.12)$ and PA $549\left({ }^{\bar{X}}=8.40\right.$, bi $=0.80$ and $S^{2} \mathrm{di}$
$=0.18$ ) found suitable for poor environment. None of the genotype was found stable for 100-seed weight across all environments Vanniarajan (2007), Reddy et al., (2011) and Pateland Tikka (2014) also observed stability of genotypes for 100 seed weight.

The results of above findings provides information that the for the trait days to $50 \%$ flowering, the check Paras was found as most stable across all environments however for days to maturity, plant height and 100-seed weight none of the genotype was found to be stable across all environments. The most desirable and suitable genotypes exhibiting higher stability for number of pod/plant across all environment was PA 538 followed by PA 540 .

\section{Declaration}

The authors are declaring that there is no conflict of interest and manuscript is not sent anywhere for publication.

\section{References}

Anonymous. 2018. Pulses Revolution-From food to nutritional security. Government of India. Ministry of Agriculture and Farmer Welfare, Krishi Bhawan, New Delhi.

Eberhart, S. A. and Russell, W.A. 1966.Stability parameters for comparing varieties. Crop Sciences., 6: 36-40.

Finlay, K.W. and Wilkinson, G.N. 1963.The analysis of adaptation in a plantbreeding programme. Australian Journal of Agricultural Research.,14: 742-754.

Gauch, H.G. and Zobel, R.W. 1996.AMMI analysis of yield trials. In: Kang, M.S., Gauch, H.G. (Eds.), Genotype by Environment Interaction, CRC, Press, Boca Raton, New York, pp. 85-122.

Gaur, A. K.,Verma, S. K., Panwar, R. K. and 
Sharma, R. K. 2020. Estimation of G x $\mathrm{E}$ interaction by AMMI model in some elite pigeonpea [Cajanus cajan(L.) Millspaugh] genotypes. Indian Journal of Genetics and Plant Breeding, 80(2) 173-178.

Gaur,A.K., Singh,I., Singh, S. and Sharma, S. 2018. Genetic analysis of $\mathrm{M}_{4}$ mutant lines of pigeonpea (Cajanus cajan (L.) Mills paugh) developed through gamma irradiation. Journal of Food Legumes, 31(2):71-74.

Kearsey, M.J. and Pooni, H.S. 1996.The genetical analysis of quantitative traits. Chapman \& Hall London, U.K.

Kumara, B.N., Dharmaraj, P.S., Kuchnur, P.H., Muniswamy, S., Yamanura., Diwan J. R. and Amaresh, Y.S. 2015. Stability analysis for yield and its attributing traits in advanced genotypes of pigeonpea [Cajanus cajan (L.) Millsp.]. Legume Research., 39(2): 194197.

Mather, K. and Jones, R. 1958.Interaction of genotype and environment in continuous variation. I. Description. Biometrics, 14:343-359.

Meena, M. R., Karuppiayan, R., Ram, B., Kumar, R. and Kulshreshtha, N. 2017. Genotypes $\mathrm{x}$ environment interactions and stability analysis of sugarcane clones (Saccharum spp.) by AMMI model in sub-tropical regions of India. Indian Journal of Genetics and Plant Breeding, 77(4): 540-546.

Meena, S. S., Verma, S. K., Choudhary, R., Nehra, M., Panwar, R. K. and Singh, J. P. 2017. Interpretation of genotype $x$ environment interaction and grain yield stability in some advance lines of pigeonpea [Cajanus cajan (L.) Millsp.] grown at different altitudes. Chemical Sciences Reviews and Letters, 6(22): 1113-1119.

Muthiah, A.R. and Kalaimagal, T. 2005. Stability analysis in hybrid pigeonpea.
Indian Journal of Pulses Research., 18(1): 76-79.

Pabale, S. S and Pandya, H. R. 2010.A comparison of different stability models for genotype $\mathrm{x}$ environment interaction in pearl millet. Electronic Journal of Plant Breeding, 1(5):1294-1298.

Patel, P. T. and Tikka, S.B.S. 2014.Gene action and stability parameters for yield and yield components, maturity duration and protein content of CGMS lines, pollen fertility restorers and their hybrids in pigeonpea. Euphytica, 199: 349-362.

Pawar, R. M., Tikka, S. B. S., Sawant, D. M. and Patil, A.D. 2013.Stability analysis for biometrical traits in pigeonpea (Cajanus cajan (L.) Millsp.). Bioinfolet., 10(4B): 1307-1311.

Plaisted, R. L. and Peterson, L.C. 1959.A technique for evaluating the ability of selections to yield consistency in different locations or seasons. American Potato Journal, 36:381-385.

Rao, A. R. and Prabhakaran, V. T. 2000. On some useful interrelationships among common stability parameters. Indian Journal of Genetics and Plant Breeding, 60(1): 25-36.

Reddy, D. K. R., Venkateswarlu, O., Obaiah, M. C. and Jyoti, G.L.S. 2011.Genotype $\mathrm{x}$ environment interaction for grain yield and its components in red gram [Cajanus cajan (L.) Millsp]. Legume Research., 34(4): 288-291.

Sawargaonkar, S. L., Saxena, K. B., Madrap, I. A. and Rathore, A. 2011.Stability analysis of yield and related traits in pigeonpea hybrids. Journal of Food Legumes, 24(3): 184-193.

Saxena, K. B., Sultana, R., Bhatnagar-Mathur, P., Saxena, R. K., Chauhan, Y.S., Kumar, R. V., Singh, I. P., Raje, R. S., and Tikle, A. N. 2016.Accomplishments and challenges of pigeonpea breeding research in India. Indian Journal of 
Genetics and Plant Breeding, 76(4): 467-482.

Singh, J., Kumar, A. and Fiyaz, R.A. 2015. Diversity and stability analysis for yield and component traits in (Cajanus cajan) under rainfed conditions. Legume Reserarch., 38 (2): 169-173.

Vanniarajan, C. 2007.Assessment of stability performance in pigeonpea. Asian Journal of Biological Sciences., 2(1): 194-195.

Verma, S. K. and Bajpai, G.C. 2002.Effect of seed size on stability for yield and associated traits in pigeonpea. Legume Research., 25(3): 202-204.
Verma, S. K., Bisht, C., Gaur, A. K. and Chandra, D. 2018.Study on some genetic parameters for yield and related traits in pigeonpea [Cajanus cajan(L.) Mills paugh] Genotypes. Chemical Sciences Reviews and Letters, 7(25): 70-76.

Yan, W. and Rajcan, I. 2002.Biplot analysis of test sites and trait relation of soybean in Ontario. Crop sciences, 42:11-20.

Yates, F. and Cochran, W. G. 1938. The analysis of groups of experiments. Journal of Agricultural sciences,28: $556-580$.

\section{How to cite this article:}

Deepak Pal, S. K. Verma, Amit Kumar Gaur, Charupriya Chauhan, Anandi Karn, Harikant Yadav and Harshdeep. 2020. Stability Analysis in Pigeonpea (Cajanus cajan (L.) Mills Paugh) Genotypes for Yield and its Component Traits. Int.J.Curr.Microbiol.App.Sci. 9(09): 264-271. doi: https://doi.org/10.20546/ijcmas.2020.909.033 